\title{
Effects of Different Levels of Dietary Energy and Nutrient Density during the Pre-Peak and Peak Periods on Egg Quality in Hy-Line Brown Laying Hens
}

\author{
Shanmugam Suresh Kumar', Vetriselvi Sampath ${ }^{2}$, Jae Hong Park ${ }^{3}$ and In Ho $\mathrm{Kim}^{3+}$ \\ ${ }^{1}$ Research Professor, Department of Animal Resource \& Science, Dankook University, Cheonan 31116, Republic of Korea \\ ${ }^{2}$ Student, Department of Animal Resource \& Science, Dankook University, Cheonan 31116, Republic of Korea \\ ${ }^{3}$ Professor, Department of Animal Resource \& Science, Dankook University, Cheonan 31116, Republic of Korea
}

\begin{abstract}
In this study, we investigated the effects of feeding diets with different levels of energy and nutrient density on the egg quality of laying hens during the pre-peak and peak periods. A total of 192 (Hy-line brown) laying hens were used in a 15-week trial. The hens were randomly allotted to one of four treatments, each with four replicates (12 hens per replication). We assessed the effects of four level of dietary energy $(2,710,2,850,2,870$ and 2,890 $\mathrm{kcal} / \mathrm{kg})$ and three levels of nutrient density (Methionine + Cysteine: $0.56 \%, 0.85 \%, 0.80 \%$ and Crude Protein: 14.5\%, 19\%, 18\%). Differences in the energy and nutrient density contents of diets showed no significant effect $(P>0.05)$ on the average daily gain, average daily feed intake, feed conversion ratio, egg weight, or egg production of hens during the pre-peak and peak periods. However, hens subjected to $2,890 \mathrm{kcal} / \mathrm{kg}$ during the pre-peak period were found to lay eggs with significantly thicker shells, and yolk color was found to be significant enhanced in hens fed this diet during the pre-and peak periods. In contrast, we detected no significant effects of dietary energy or nutrient density on the Haugh unit or eggshell strength. In summary, increasing the energy level of diets from 2,710 to $2,890 \mathrm{kcal} / \mathrm{kg}$ was found to have positive effects on the shell thickness and yolk color of eggs produced by laying hens.
\end{abstract}

(Key words: laying hens, egg weight, egg production, egg quality)

\section{INTRODUCTION}

Over the past decades, nutritional supplements were added in animal meals to enhances the quality and quantity of animal products. The formulation of poultry feed is based on the concept that poultry tend to meet their energy needs, assuming that the diet is adequate in all other essential nutrients. Owing to this concept, the crude proteins and amino acids added to the poultry diet should be proportionate to meet the metabolizable energy concentration (NRC, 1984). As of the assumption that laying hens require less high-energy diet meaning that they will only eat to meet their energy requirement, and since the ingredients in high-energy diet include corn grain, vegetable oil, etc., which are quite expensive, often low-energy feeds are also fed. Though low-energy diets are fed and the energy requirement for laying hens may not seem sufficient, hens can regulate their feed intake rate to maintain their energy requirement (Harms et al., 2000; Leeson et al., 2001; Wu et al., 2005, 2007). Birds of low body weight, and low inherent feed intake efficiently meet their energy requirements by adjusting to their feed intake in place of changing diet nutrient density, therefore by increasing their feed intake in response to marginal levels of first limiting amino acids, independent of diet energy level (Keshavarz and Nakajima, 1995).

$\mathrm{Wu}$ et al. (2005b) suggested that increasing the dietary proteins and amino acids in diet may prevent the interfering effect of decreased nutrient intake on egg weight so that the true effect of increasing dietary energy on egg weight could be determined. The better understanding of the effect of increasing both dietary energy and other nutrients (amino acids, $\mathrm{Ca}$, and available $\mathrm{P}$ ) may help egg producers to optimize early egg weight to improve profits, especially when a large egg price spread due to egg size exists. The main problem that concerns the poultry producers are small egg size in young hens during peak production, and if egg weight

† To whom correspondence should be addressed : inhokim@dankook.ac.kr 
can be improved, poultry producers will be able to improve profits, depending upon egg price, egg size, and ingredient prices. Therefore, the objective of our present study was to investigate the effects of varied energy and nutrients density diets during the pre-peak and peak period on egg quality in laying hens.

\section{MATERIALS AND METHODS}

The experiment protocol was reviewed and approved (DK-1-2012) by the Animal Care and Use Committee of Dankook University (Cheonan, Republic of Korea).

\section{Experimental Design, Birds, and Housing}

A total of 192 (Hy-line brown) laying hens were used in a 15-week trial as pre-peak and peak period (growing period -0-7 weeks, pre-peak period -7-13 weeks and peak period
-13-15 weeks). Laying hens were randomly allotted to 1 of 4 treatments with 4 replications (12 hens per replication). The four level of dietary energy supplements were: 2,710, 2,850, 2,870 and $2,890 \mathrm{kcal} / \mathrm{kg}$, and the three different level of nutrient density were: Methionine + Cysteine, \%: 0.56, 0.85, 0.80 and Crude Protein, \%: 14.5, 19, 18. From weeks 1-7 laying hens were fed with: CON (basal diet), TRT1, TRT2, and TRT3-CP: 14.5\% (M+C: 0.56)/ ME: 2,710, whereas from weeks 7-13 hens were offered to had : CON, CP: 14.5\% (M+C: 0.56)/ ME: 2,710; TRT1, CP: 19\% (M+C: 0.85)/ ME: 2,850; TRT2, CP: 19\% (M+C: 0.85)/ ME: 2,870; TRT3, CP: 19\% (M+C: 0.85)/ ME: 2,890, and from weeks -13-15-CON, TRT1, TRT2, and TRT3 - CP: 18\% (M+C: 0.80)/ ME: 2,850. Ingredients and nutrient composition of experimental diets are shown in Table 1. All nutrients diets were formulated to meet or exceed the recommendation of NRC (1994). The laying hens were individually caged and provided with free access to water and feed by nipple

Table 1. Ingredient composition of experimental diets as-fed basis

\begin{tabular}{|c|c|c|c|c|c|}
\hline Raw material & $\begin{array}{c}\mathrm{CP}: 14.5 \% \\
(\mathrm{M}+\mathrm{C}: 0.56) / \\
\mathrm{ME}: 2,710\end{array}$ & $\begin{array}{c}\mathrm{CP}: 19 \%(\mathrm{M}+\mathrm{C}: \\
0.85) / \mathrm{ME}: 2,850 \\
\mathrm{kcal} / \mathrm{kg})\end{array}$ & $\begin{array}{c}\mathrm{CP}: 19 \%(\mathrm{M}+\mathrm{C}: \\
0.85) / \mathrm{ME}: 2,870 \\
\mathrm{kcal} / \mathrm{kg})\end{array}$ & $\begin{array}{c}\mathrm{CP}: 19 \%(\mathrm{M}+\mathrm{C}: \\
0.85) / \mathrm{ME}: 2,890 \\
\mathrm{kcal} / \mathrm{kg})\end{array}$ & $\begin{array}{c}\mathrm{CP}: 18 \%(\mathrm{M}+\mathrm{C}: \\
0.80) / \mathrm{ME}: \\
2,850 \mathrm{kcal} / \mathrm{kg})\end{array}$ \\
\hline Corn (Non-GMO) & 51.01 & 49.01 & 48.53 & 48.06 & 50.61 \\
\hline Wheat & 6 & 4 & 4 & 4 & 5 \\
\hline Soy (full fat) & 3 & 8 & 8 & 8 & 8 \\
\hline Wheat Bran & 16 & & & & \\
\hline Soy bean meal (Non-GMO) & 3.42 & 8.46 & 8.54 & 8.63 & 5.19 \\
\hline Canola meal & 1 & 1 & 1 & 1 & 1 \\
\hline Corn gluten meal (Non-GMO) & 1.72 & 7 & 7 & 7 & 7 \\
\hline Sesame Meal & 4.5 & 4.5 & 4.5 & 4.5 & 4.5 \\
\hline $\begin{array}{l}\text { DDGS (distiller's dried grains with } \\
\text { soluble)- Corn }\end{array}$ & 4 & 4 & 4 & 4 & 4 \\
\hline Palm kernel meal & 3 & & & & 1.47 \\
\hline Tallow & 0.5 & 0.86 & 1.26 & 1.66 & 0.5 \\
\hline Molasses (Cane) & 0.5 & 0.5 & 0.5 & 0.5 & 0.5 \\
\hline Limestone & 3.45 & 10.12 & 10.12 & 10.11 & 9.95 \\
\hline MDCP (Mono dicalcium Phosphate) & 0.97 & 1.1 & 1.1 & 1.1 & 0.75 \\
\hline Salt & 0.17 & 0.1 & 0.1 & 0.1 & 0.02 \\
\hline $\mathrm{NaHCO}_{3}$ (Sodium bicarbonate) & 0.21 & 0.28 & 0.28 & 0.27 & 0.4 \\
\hline
\end{tabular}


Table 1. Continued

\begin{tabular}{|c|c|c|c|c|c|}
\hline Raw Material & $\begin{array}{c}\mathrm{CP}: 14.5 \% \\
(\mathrm{M}+\mathrm{C}: 0.56) / \\
\mathrm{ME}: 2,710\end{array}$ & $\begin{array}{c}\mathrm{CP}: 19 \%(\mathrm{M}+\mathrm{C}: \\
0.85) / \mathrm{ME}: 2,850 \\
\mathrm{kcal} / \mathrm{kg})\end{array}$ & $\begin{array}{c}\mathrm{CP}: 19 \%(\mathrm{M}+\mathrm{C}: \\
0.85) / \mathrm{ME}: 2,870 \\
\mathrm{kcal} / \mathrm{kg})\end{array}$ & $\begin{array}{c}\mathrm{CP}: 19 \%(\mathrm{M}+\mathrm{C}: \\
0.85) / \mathrm{ME}: 2,890 \\
\mathrm{kcal} / \mathrm{kg})\end{array}$ & $\begin{array}{c}\mathrm{CP}: 18 \%(\mathrm{M}+\mathrm{C}: \\
0.80) / \mathrm{ME}: \\
2,850 \mathrm{kcal} / \mathrm{kg})\end{array}$ \\
\hline Methionine $(99 \%)$ & 0.01 & 0.18 & 0.18 & 0.18 & 0.15 \\
\hline Lysine $(50 \%)$ & 0.24 & 0.46 & 0.46 & 0.46 & 0.51 \\
\hline Threonine (98.5\%) & & 0.02 & 0.02 & 0.02 & 0.02 \\
\hline Tryptophan $(20 \%)$ & & 0.09 & 0.09 & 0.09 & 0.11 \\
\hline Vitamin premix & 0.12 & 0.12 & 0.12 & 0.12 & 0.12 \\
\hline Choline $(50 \%)$ & 0.08 & 0.1 & 0.1 & 0.1 & 0.1 \\
\hline Mineral premix & 0.1 & 0.1 & 0.1 & 0.1 & 0.1 \\
\hline \multicolumn{6}{|l|}{ Calculated value } \\
\hline Moisture (\%) & 11.55 & 10.01 & 9.95 & 9.9 & 10.06 \\
\hline Crude protein $(\%)$ & 14.5 & 19 & 19 & 19 & 18 \\
\hline Crude fat $(\%)$ & 4.6 & 5.29 & 5.67 & 6.05 & 5.07 \\
\hline Crude fiber (\%) & 4.24 & 2.8 & 2.79 & 2.79 & 2.87 \\
\hline Crude ash (\%) & 7.72 & 14.49 & 14.49 & 14.49 & 13.94 \\
\hline $\mathrm{ME}(\mathrm{kcal} / \mathrm{kg})$ & 2,710 & 2,850 & 2,870 & 2,890 & 2,850 \\
\hline $\mathrm{Ca}(\%)$ & 1.6 & 4.12 & 4.12 & 4.12 & 4 \\
\hline Available P (\%) & 0.45 & 0.45 & 0.45 & 0.45 & 0.39 \\
\hline Methionine + Cysteine $(\%)$ & 0.56 & 0.85 & 0.85 & 0.85 & 0.8 \\
\hline
\end{tabular}

${ }^{1}$ Provided per kilograms of diet: vitamin $\mathrm{A}, 10,800 \mathrm{IU}$; vitamin $\mathrm{D}_{3}, 4,000 \mathrm{IU}$; vitamin $\mathrm{E}$, $40 \mathrm{IU}$; vitamin $\mathrm{K}_{3}, 4 \mathrm{mg}$; vitamin $\mathrm{B}_{1}, 6 \mathrm{mg}$; vitamin $\mathrm{B}_{2}, 12 \mathrm{mg}$; vitamin $\mathrm{B}_{6}, 6 \mathrm{mg}$; vitamin $\mathrm{B}_{12}, 0.05 \mathrm{mg}$; biotin, $0.2 \mathrm{mg}$; folic acid, $2 \mathrm{mg}$; niacin, $50 \mathrm{mg}$; D-calcium pantothenate, $25 \mathrm{mg}$.

${ }^{2}$ Provided per $\mathrm{kg}$ diet: $\mathrm{Fe}, 100 \mathrm{mg}$ as ferrous sulfate; $\mathrm{Cu}, 17 \mathrm{mg}$ as copper sulfate; $\mathrm{Mn}, 17 \mathrm{mg}$ as manganese oxide; $\mathrm{Zn}, 100 \mathrm{mg}$ as zinc oxide; I, $0.5 \mathrm{mg}$ as potassium iodide; and $\mathrm{Se}, 0.3 \mathrm{mg}$ as sodium selenite.

drinkers and feeders. Room temperature was maintained at $21 \pm 1^{\circ} \mathrm{C}$ and had a daily lighting schedule of sixteen hours light and eight hours dark.

\section{Sampling and Laboratory Analysis}

Body weight measurement was done at initial, week 11, and week 15. Average daily gain (ADG), average daily feed intake (ADFI), and feed conversion ratio (FCR) were calculated and daily records of egg production was maintained. The production of egg was expressed as an average hen-day production. Also, the quality of the egg was checked alternative week from week 9 to 15 . A total of 120 eggs (30-eggs each treatment) from each treatment was randomly selected and the quality of eggs were analyzed on the same day. The egg weight, shell strength, yolk, and Haugh Unit were measured using an egg multi tester (Touhoku Rhythm Co. Ltd., Tokyo, Japan). Eggshell breaking strength was determined with the eggshell force gauge (model II, Robotmation Co., Ltd., Tokyo, Japan). A dial pipe gauge (Ozaki MFG. Co., Ltd., Tokyo, Japan) was used to measure eggshell thickness, which was determined based on the average thickness of the rounded end, pointed end, and the middle of the egg, excluding the inner membrane.

\section{Statistical Analysis}

All the data were analyzed using the GLM procedure of 
the SAS program SAS (Inst. Inc., Cary, NC) Software package (2000). The Duncan's multiple test was performed to determine the significant difference. The data were expressed as the standard error of the mean (SEM), and $P$ values $<0.05$ were considered as statistical significance and $P$ values $<0.10$ as trend.

\section{RESULTS AND DISCUSSIONS}

The effects of variation in energy and nutrient density of the experimental diets on growth performance and egg production in laying hens is shown in Table 2. No significant difference was observed on egg weight with the variation in energy and nutrient density diets during pre-peak and peak period ( $P>0.05)$. Similarly, Wu et al. (2005) reported that egg weight did not have any significant effect with an increasing level of dietary energy from 2,877 to 2,956 kcal of ME/kg. However, earlier studies reported inconsistent results, that increasing dietary fat or dietary energy had significantly improved early egg weight (Keshavarz, 1995; Keshavarz and Nakajima, 1995; Grobas et al., 1999; Harms et al., 2000; Bohnsack et al., 2002; Sohail et al., 2003; Wu et al., 2005b). $\mathrm{Wu}$ et al. (2005b) demonstrated that an ideal dietary energy: protein is required for optimal performance of laying hens thereby having an impact on egg weight. DePersio et al. (2015) in their study indicated that feeding energy and nutrient rich diet to hens will increase egg production, egg weight, and BW. In the present study, the different levels of energy and nutrient density diets did not have any significant effects $(P>0.05)$ on $\mathrm{BW}$, ADFI, FCR, and egg production during pre-peak and peak period. However, except early production cycle there were no significant results observed with the increasing energy and nutrient density diets. Rao et al. (2014) stated that increased feed intake occurred between 21 to 72 weeks of age, when the birds were fed a diet containing 2,399 vs. 2,550 vs. $2,700 \mathrm{kcal} / \mathrm{kg} \mathrm{ME}$, respectively.

Table 2. The effects of different level of energy and nutrient density on growth performance and egg production in laying hens ${ }^{1}$

\begin{tabular}{|c|c|c|c|c|c|c|}
\hline Items & $\mathrm{CON}$ & TRT1 & TRT2 & TRT3 & $\mathrm{SEM}^{2}$ & $P$ value \\
\hline \multicolumn{7}{|l|}{ Growing } \\
\hline BW (g) & 1,583 & 1,616 & 1,655 & 1,641 & 0.52 & 0.6023 \\
\hline ADFI (g) & 80.92 & 81.14 & 80.13 & 80.11 & 0.59 & 0.5436 \\
\hline \multicolumn{7}{|l|}{ Pre-peak (11 week) } \\
\hline BW (g) & 1,809 & 1,788 & 1,813 & 1,805 & 1.30 & 0.6023 \\
\hline ADFI (g) & 89.64 & 92.49 & 89.53 & 91.82 & 1.06 & 0.1812 \\
\hline Egg production, \% & 70.07 & 67.43 & 68.89 & 62.15 & 3.67 & 0.6037 \\
\hline Egg weight, g & 48.23 & 49.95 & 48.63 & 50.56 & 1.22 & 0.9596 \\
\hline FCR & 3.053 & 3.368 & 3.150 & 3.094 & 0.173 & 0.4081 \\
\hline \multicolumn{7}{|l|}{ Peak (15 week) } \\
\hline BW (g) & 1,889 & 1,840 & 1,864 & 1,887 & 1.35 & 0.6023 \\
\hline ADFI (g) & 96.50 & 97.50 & 97.39 & 97.92 & 0.64 & 0.4111 \\
\hline Egg production (\%) & 90.72 & 93.84 & 93.37 & 89.77 & 2.52 & 0.6037 \\
\hline Egg weight (g) & 53.56 & 53.93 & 53.89 & 53.94 & 0.58 & 0.4596 \\
\hline FCR & 1.898 & 1.840 & 1.879 & 1.938 & 0.056 & 0.6782 \\
\hline
\end{tabular}

${ }^{1}$ Abbreviation: $1-7$ weeks - CON, TRT1, TRT2, TRT3, CP: $14.5 \%$ (M+C: 0.56)/ ME: 2,710; 7-13 weeks - CON, CP: $14.5 \%$ (M+C: 0.56)/ ME: 2,710; TRT1, CP: 19\% (M+C: 0.85)/ ME: 2,850; TRT2, CP: 19\% (M+C: 0.85)/ ME: 2,870; TRT3, CP: 19\% (M+C: 0.85)/ ME: 2,890; 13-15 weeks - CON, TRT1, TRT2, TRT3, CP: 18\% (M+C: 0.80)/ ME: 2,850.

2 Standard error of means. 
Moreover, Jalal et al. (2007) showed that the feed intake in Hy-Line W-36 hens was not improved when fed a low-energy diet (2,810 vs. $2,900 \mathrm{kcal} \mathrm{ME} / \mathrm{kg}$ ). During early stages of lay cycle, the nutrient requirements for younger and older hen differs, where younger ones require higher nutrient concentrations than older ones due to low feed intake (NRC, 1994). Harms et al. (2000) and $\mathrm{Wu}$ et al. (2005) also indicated that egg production was not affected by dietary energy. DePersio et al. (2015) studies showed that $85 \%$ treatments were not effective in young birds to reach production in the first phase, furthermore, laying hen does not have the capacity to increase its feed intake when fed a diet of low nutrient-density. In this study, the reason behind this problem might be due to the variation in low nutrient density, which can result in low feed intake and low egg production in the early lay cycle.

Previously, Zhang and Kim (2013) and Kang et al. (2018) reported that the eggshell thickness, eggshell strength, yolk color, and Haugh unit were not affected by inclusion of energy and nutrient density diets (2,700 or $2,800 \mathrm{kcal} / \mathrm{kg} \mathrm{ME})$ during 0 to 6 weeks. Similarly, Ribeiro et al. (2014) did not find any influence of dietary energy level 2,700 to 3,000 $\mathrm{kcal} / \mathrm{kg}$ on eggshell percentage, yolk color, HU of layer eggs. The effects of different levels of energy and nutrient density on egg quality in laying hens is shown in Table 3. The quality parameter which usually depends on retailer's desire

Table 3. The effects of different level of energy and nutrient density on egg quality in laying hens ${ }^{1}$

\begin{tabular}{|c|c|c|c|c|c|c|}
\hline Items & $\mathrm{CON}$ & TRT1 & TRT2 & TRT3 & $\mathrm{SEM}^{2}$ & $P$ value $^{3}$ \\
\hline \multicolumn{7}{|l|}{ Pre-peak (Week 9) } \\
\hline Haugh unit & 70.85 & 61.04 & 67.38 & 64.76 & 4.84 & 0.5375 \\
\hline Yolk color & 10.31 & 10.13 & 10.44 & 10.13 & 0.17 & 0.4853 \\
\hline Eggshell strength, $\mathrm{kg} / \mathrm{cm}^{2}$ & 5.20 & 4.56 & 4.70 & 4.71 & 0.20 & 0.1268 \\
\hline Eggshell thickness, mm & $35.33^{\mathrm{b}}$ & $38.60^{\mathrm{a}}$ & $38.81^{\mathrm{a}}$ & $39.04^{\mathrm{a}}$ & 0.45 & 0.0003 \\
\hline \multicolumn{7}{|l|}{ Pre-peak (Week 11) } \\
\hline Haugh unit & 77.39 & 76.90 & 78.78 & 82.73 & 6.40 & 0.9160 \\
\hline Yolk color & $9.75^{\mathrm{b}}$ & $9.88^{\mathrm{ab}}$ & $10.13^{\mathrm{a}}$ & $10.19^{\mathrm{a}}$ & 0.11 & 0.0383 \\
\hline Eggshell strength, $\mathrm{kg} / \mathrm{cm}^{2}$ & 4.67 & 5.21 & 4.76 & 5.19 & 0.19 & 0.1051 \\
\hline Eggshell thickness, mm & $37.73^{\mathrm{b}}$ & $37.96^{\mathrm{b}}$ & $44.88^{\mathrm{a}}$ & $46.69^{\mathrm{a}}$ & 0.64 & $<0.0001$ \\
\hline \multicolumn{7}{|l|}{ Peak (Week 13) } \\
\hline Haugh unit & 66.84 & 73.97 & 77.05 & 77.07 & 4.35 & 0.3080 \\
\hline Yolk color & 9.10 & 8.70 & 8.95 & 8.95 & 0.20 & 0.5611 \\
\hline Eggshell strength, $\mathrm{kg} / \mathrm{cm}^{2}$ & 5.35 & 5.49 & 5.40 & 5.07 & 0.18 & 0.3688 \\
\hline Eggshell thickness, mm & 38.38 & 38.40 & 38.38 & 38.58 & 0.30 & 0.2001 \\
\hline \multicolumn{7}{|l|}{ Peak (Week 15) } \\
\hline Haugh unit & 77.59 & 83.70 & 80.74 & 78.47 & 4.60 & 0.7884 \\
\hline Yolk color & 8.50 & 8.75 & 8.25 & 8.50 & 0.15 & 0.1336 \\
\hline Eggshell strength, $\mathrm{kg} / \mathrm{cm}^{2}$ & 4.59 & 4.65 & 4.70 & 4.51 & 0.20 & 0.9125 \\
\hline Eggshell thickness, mm & 38.88 & 38.83 & 39.25 & 40.62 & 0.48 & 0.1856 \\
\hline
\end{tabular}

${ }^{1}$ Abbreviation: 1-7 weeks - CON, TRT1, TRT2, TRT3, CP: $14.5 \%$ (M+C: 0.56)/ ME: 2,710; 7-13 weeks - CON, CP: $14.5 \%$ (M+C: 0.56)/ ME: 2,710; TRT1, CP: $19 \%$ (M+C: 0.85)/ ME: 2,850; TRT2, CP: 19\% (M+C: 0.85)/ ME: 2,870; TRT3, CP: $19 \%$ (M+C: 0.85)/ ME: 2,890; 13-15 weeks - CON, TRT1, TRT2, TRT3, CP: 18\% (M+C: 0.80)/ ME: 2,850.

2 Standard error of means.

${ }^{3}$ Means in the same row with different superscripts differ $(P<0.05)$. 
in eggs is the color of the yolk, because consumers associate this parameter with high nutritional value and vitamin content (Galobart et al., 2004; Zhang and Kim, 2011). In the current study, the yolk color showed significant improvement $(P=0.0383)$ in treatment 3 at the pre-peak period (week 11). Silva et al. (2007) found that, laying hen when fed with diet containing high oil content tend to have higher yolk color values. In the present study, the supplementation of energy $(2,710$ to $2,890 \mathrm{kcal} / \mathrm{kg})$ and nutrient density into the diet of laying hens significantly increased eggshell thickness in 2,890 $\mathrm{kcal} / \mathrm{kg}$ during the pre-peak period (week 9 and 11). Junqueira et al. (2006) stated that eggshell percentage had significant effect by the addition of different level of energy in diets. The results stated by Grobas et al. (1999) showed no effect in egg shell quality in 22 to 75 weeks age laying hens in different dietary energy (2,700 to $3,000 \mathrm{kcal}$ of $\mathrm{ME} / \mathrm{kg})$ levels. In contrast, Mendonca and Lima (1999) evaluated that laying hens early in the second productive cycle which are fed with a diet of $14.5 \%$ protein than those from birds fed diets with $16.5 \%$ protein found better eggshell quality. Haugh unit is a measure of the freshness of an egg. In a study conducted by Junqueira et al. (2006) failed to observe any significant effects on Haugh units of eggs, $(P>0.05)$ obtained from layers fed different levels of energy. (2,850;2,950, and 3,050 $\mathrm{kcal}$ of $\mathrm{ME} / \mathrm{kg}$ ) and protein $(16,18$, and $20 \% \mathrm{CP})$. Similarly, Zimmermann and Andrews (1987) compared diets with 2 levels of metabolizable energy $(3,100$ or $2,920 \mathrm{kcal}$ of $\mathrm{ME} / \mathrm{kg}$ ) and 2 levels of protein (14.6 and 15.5\%) on performances of laying hens and did not find any effect on Haugh units. In our study, Haugh unit was not affected in the pre-peak period and peak period by feeding the birds with diets containing different levels of energy and protein. In contrast, Silva et al. (2007) found a positive quadratic effect in Haugh units as dietary metabolizable energy intake increased, whereas $\mathrm{Wu}$ et al. $(2005,2007)$ reported a reduction in $\mathrm{HU}$ values as dietary metabolizable energy concentration increased. The contradiction between the various study results might be due to the age of hens, composition of dietary energy and nutrients level.

\section{SUMMARY}

In conclusion, eggshell thickness and yolk color had positive effects due to the increasing energy level from 2,710 to $2,890 \mathrm{kcal} / \mathrm{kg}$ during the pre-peak period. The difference in the levels of energy and nutrient density in the diets failed to show significant effects on BW, ADFI, FCR, and egg production during pre-peak and peak period. Also, eggshell strength and HU had no effect by formulating the diets with varying energy, amino acids and protein levels. Among the four treatments, 2,890 kcal/kg was better than control and other treatments. Therefore, we conclude that an energy level that ranges between 2,710 to $2,890 \mathrm{kcal} / \mathrm{kg}$ would be potential to improve the quality of eggs.

\section{ORCID}

\author{
Shanmugam Suresh Kumar \\ https://orcid.org/0000-0001-5160-323X \\ Vetriselvi Sampath https://orcid.org/0000-0002-6726-8568 \\ Jae Hong Park https://orcid.org/0000-0002-2025-0141 \\ In Ho Kim https://orcid.org/0000-0001-6652-2504
}

\section{REFERENCES}

Bohnsack CR, Harms RH, Merkel WD, Russell GB 2002 Performance of commercial layers when fed diets with four contents of corn oil or poultry fat. J Appl Poult Res 11:68-76.

DePersio S, Utterback PL, Utterback CW, Rochell SJ, O'Sullivan N, Bregendahl K, Arango J, Parsons CM, Koelkebeck KW 2015 Effects of feeding diets varying in energy and nutrient density to Hy-Line W-36 laying hens on production performance and economics. Poult 94:195-206.

Galobart J, Sala R, Rincon-Carruyo X, Manzanilla EG, Vila B, Gasa J 2004 Egg yolk color as affected by saponification of different natural pigmenting sources. J Appl Poult Res 13:328-334.

Grobas S, Mendez J, De Blas C, Mateos GG 1999 Laying hen productivity as affected by energy, supplemental fat, and linoleic acid concentration of the diet. Poult 78:1542-1551. 
Harms RH, Russell GB, Sloan DR 2000 Performance of four strains of commercial layers with major changes in dietary energy. J Appl Poult Res 9:535-541.

Jalal MA, Scheideler SE, Pierson EM 2007 Strain response of laying hens to varying dietary energy levels with and without Avizyme supplementation. J Appl Poult Res 16:289-295.

Junqueira OM, De Laurentiz AC, da Silva Filardi R, Rodrigues EA, Casartelli EMC 2006 Effects of energy and protein levels on egg quality and performance of laying hens at early second production cycle. J Appl Poult Res 15:110-115.

Kang HK, Park SB, Jeon JJ, Kim HS, Park KT, Kim SH, Hong EC, Kim CH 2018 Effect of increasing levels of apparent metabolizable energy on laying hens in barn system. Asian-Australas J Anim Sci 31:1766-1772.

Keshavarz K. 1995 Further investigations on the effect of dietary manipulations of nutrients on early egg weight. Poult 74:62-74.

Keshavarz K, Nakajima S 1995 The effect of dietary manipulations of energy, protein, and fat during the growing and laying periods on early egg weight and egg components. Poult 74:50-61.

Leeson S, Summers JD, Caston LJ 2001 Response of layers to low nutrient density diets. J Appl Poult Res 10:46-52. Mendonca CX, Lima FR 1999 Effect of dietary protein and methionine levels on forced molted performance of laying hens. Braz J Vet Res Anim Sci 6:332-338.

NRC, Nutrient Requirement of Poultry 1994 9th rev. ed. National Academy Press, Washington, DC.

NRC, Nutrient Requirement of Poultry 1984 8th rev. ed. National Research Council. National Academy Press. Washington, DC.

Rao S, Rama V, Ravindran V, Raju MVLN, Srilatha T, Panda AK 2014 Effect of different concentrations of metabolizable energy and protein on performance of White Leghorn layers in a tropical climate. Br. Poult. Sci 55:532-539.

Ribeiro PDAP, Matos Jr JB, Lara LJC, Araújo LF,
Albuquerque RD, Baião NC 2014 Effect of dietary energy concentration on performance parameters and egg quality of white leghorn laying hens. Br Poult Sci 16:381-388.

Silva ABP da, Burini RC, Silva EMP da, Garcia EA, Pizzolante CC, Saldanha Érika SPB, Deodato AdeP, Molino AdeB 2008 Effect of energy and vegetable oil consumption on the quality of semi-heavy laying eggs. $\mathrm{R}$. Bras. Zootec 8:647-656.

Sohail SS, Bryant MM, Roland Sr DA 2003 Influence of dietary fat on economic returns of commercial Leghorns. J Appl Poult Res 12:356-361.

Wu G, Bryant MM, Voitle RA, Roland Sr DA 2005 Effect of dietary energy on performance and egg composition of Bovans White and DeKalb White hens during phase 1. Poult 84:1610-1615.

Wu G, Bryant MM, Voitle RA, Roland Sr DA 2005a. Influences of dietary energy and protein levels on performance of Hyline W-36 hens in phase I. Poult 84:50 (Abstr).

Wu G, Bryant MM, Gunawardana P, Roland Sr DA 2007 Effect of nutrient density on performance, egg components, egg solids, egg quality, and profits in eight commercial leghorn strains during phase one. Poult 86:691-697.

Wu G, Bryant MM, Voitle RA, Roland Sr DA 2005b Effect of dietary energy on performance and egg composition of Bovans White and Dekalb White hens during phase 1. Poult 84:1610-1615

Zhang ZF, Kim IH 2013 Effects of probiotic supplementation in different energy and nutrient density diets on performance, egg quality, Excreta microflora, excreta noxious gas emission, and serum cholesterol concentrations in laying hens. Anim. Sci. J 91:4781-4787.

Zimmermann NG, Andrews DK 1987 Comparison of several induced molting methods on subsequent performance of single comb white Leghorn hens. Poult 66:408-417.

Received Dec. 6, 2021, Revised Dec. 22, 2021, Accepted Dec. 24,2021 
